\title{
The Impact of Organizational Career Management towards Employees' Career Satisfaction
}

Nur Intan Izzati Binti Mohd Nasir, Rabeatul Husna Abdull Rahman, Nur Syafiqah A. Rahim, Noraini Rusbadrol, Faizah Mohd Fakhruddin

To Link this Article: http://dx.doi.org/10.6007/IJARBSS/v11-i11/11244 DOI:10.6007/IJARBSS/v11-i11/11244

Received: 08 September 2021, Revised: 11 October 2021, Accepted: 27 October 2021

Published Online: 17 November 2021

In-Text Citation: (Nasir et al., 2021)

To Cite this Article: Nasir, N. I. I. B. M., Rahman, R. H. A., Rahim, N. S. A., Rusbadrol, N., \& Fakhruddin, F. M. (2021). The Impact of Organizational Career Management towards Employees' Career Satisfaction. International Journal of Academic Research in Business and Social Sciences, 11(11), 1480-1492.

Copyright: (C) 2021 The Author(s)

Published by Human Resource Management Academic Research Society (www.hrmars.com)

This article is published under the Creative Commons Attribution (CC BY 4.0) license. Anyone may reproduce, distribute, translate and create derivative works of this article (for both commercial and non0-commercial purposes), subject to full attribution to the original publication and authors. The full terms of this license may be seen

at: http://creativecommons.org/licences/by/4.0/legalcode

Vol. 11, No. 11, 2021, Pg. $1480-1492$

Full Terms \& Conditions of access and use can be found at http://hrmars.com/index.php/pages/detail/publication-ethics 


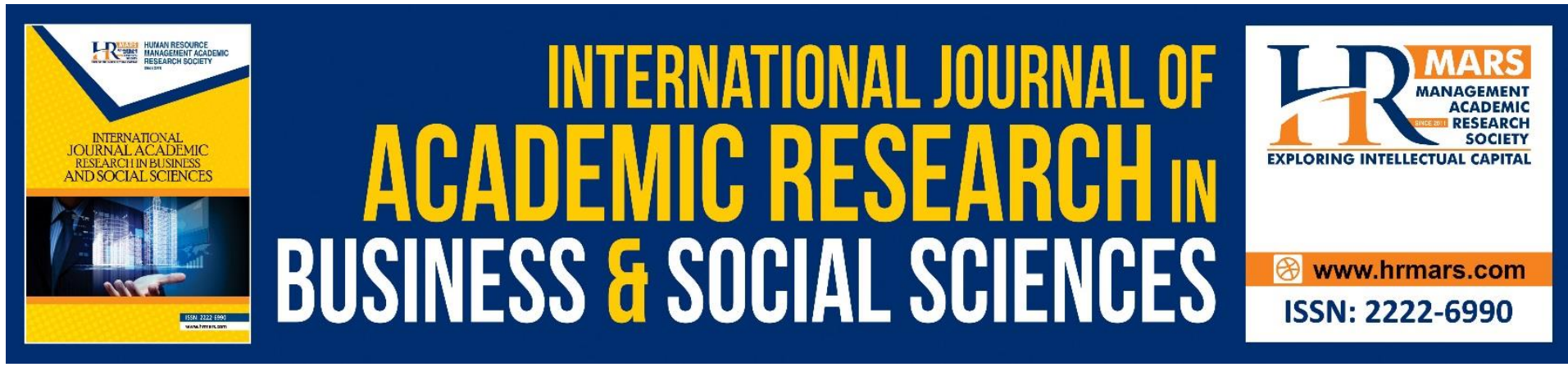

\title{
The Impact of Organizational Career Management towards Employees' Career Satisfaction
}

\author{
Nur Intan Izzati Binti Mohd Nasir, Rabeatul Husna Abdull \\ Rahman, Nur Syafiqah A. Rahim, Noraini Rusbadrol, Faizah \\ Mohd Fakhruddin \\ Department of Human Resource Development and Psychology, Faculty of Social Sciences \\ and Humanities, Universiti Teknologi Malaysia, Johor Bahru, Johor, Malaysia. \\ Email: rabeatulhusna@utm.my
}

\begin{abstract}
This study was aimed to investigate the impact of organizational career management towards career satisfaction among employees in a private firm in Johor Bahru, Malaysia. A total of 101 respondents were involved in this study. Questionnaire was used to collect the data and the data was analysed using statistical software to describe the descriptive and inferential statistics. The findings showed a positive and significant impact of organizational career management towards the employees' career satisfaction. Organizational career management practices such as career planning, counselling sessions, training and workshops, mentoring, job rotation and others have given an influence to the employees' career satisfaction. The findings suggested that employees' can improve their knowledge, skills, and abilities (KSA) as well as sustain employees' commitment through career management activities.
\end{abstract}

Keywords: Career Management, Career Development, Career Satisfaction, Career Success, Career Planning

\section{Introduction}

In this era of globalization and technology advancement, organization might face some challenges that would give a negative effect towards employees' career. Therefore, organization play a huge role in managing employees' career that can help to develop their knowledge, skills and abilities (KSA). Career management is a process that involves organization planning, designing and implementation of career practices that can help employees to achieve their goals. Organization career management can be viewed as formal activities (training programs, career planning) and informal activities (mentoring, networking opportunities). As stated by Naqvi et al (2013), formal and informal activities of career management can help the employees to take advantage of opportunities in the organization.

In the effort to develop employees' career, organization should ensure their career management planning involved both individual and organization needs. This processes not only can make employees to feel valued in the organization, but it also can increase employees' satisfaction. Generally, employees' career satisfaction can be measured through 
the employees' job satisfaction (Rahim \& Rohaida, 2015). A study conducted by Tresna et al (2019) found that when the employees received better career management, the satisfaction towards the job is high. According to Dorasamy and Letooane (2015), employees are satisfied with their job if the organizations develop their career by providing training, giving them opportunities to apply their new skills and knowledge towards their jobs and when they can achieve their career goals. In other words, employees would be satisfied with their jobs when they've become more expert and knowledgeable as result of undergoing the trainings and development programs.

Past studies have shown evidence of the link between career management and employees' career satisfaction. For instance, (Hsiao, 2013; Kiong and Yin-Fah, 2016; Uysal et al., 2015). However, these variables are less researched in the context of Malaysian firms. Besides, many past studies have looked at job satisfaction as opposed to career satisfaction. Hence this study was conducted to explore the impact of career management practices in a Malaysian firm on the employees' career satisfaction.

\section{Research Objectives}

The research objectives are as follows:

i. To determine the level of employees' perceived career management practices

ii. To determine the level of employees' perceived career satisfaction

iii. To determine the impact of organizational career management on career satisfaction

\section{Literature Review \\ Career Management}

According to Seema and Sujatha (2013), organizational career management is policies and practices that have been planned by the organization to improve the employees' career success. Organizational career management also refers to the tasks performed by the organization to manage the employees' career, which includes broad schemes and interactions based on the individualistic and organizational needs (Rezaean et al., 2012). Training and development are one of the practices that can be provided by the organization or employer to their employees (Ogar et al., 2019).

Organizational career management includes of career planning and development. Career planning can be defined as the decision-making process that includes the target of individuals, personal characteristics and social interaction. Organization can identify individual's needs by involving their employees in the career planning. Besides that, career development refers to the individual's effort to improve their skills and capabilities, and achieve their career goals such as promotion, and status (Albay and Serbes, 2017). Therefore, organization should provide an opportunity to their employees that can help them receive continuous learning practices.

\section{Theory of Career Management: Traits-Factor Theory}

According to Atli (2016), intelligence, attention and ability can be defined as traits meanwhile factors can be defined as the individual's competencies to achieve career success. Based on this theory, there are 3 phases of career choices that includes recognition of individual's self, gathering information related to the career and business world, and combination of 
recognition of individual's self and gathering information related to the career and business world.

Recognition of individual's self is a phase that includes of individual's self-interests, abilities, and emotions (Atli, 2016). In the management of employees' careers, organization should identify all of those traits in order to help them plan and guide employees in achieving their career goals. Other than that, gathering information related to the career and business world are also important to ensure all of those traits can be matched with the employees' career goals. In addition, by combining recognition of individual's self and gathering information related to the career and business world, organization can plan their employees' career according to the career and business world requirement. In summary, all of these three phases can help organization in managing employees' careers by matching individual's traits and business goals.

\section{Career Satisfaction}

Career satisfaction is one of the elements in the subjective career success. According to Chen (2010), subjective career success can be highlighted through two components, which is career satisfaction and job satisfaction. Subjective career success is measured by using the job satisfaction scale (Hofmans et al., 2008). According to Mishra (2013), job satisfaction refers to a general attitude that results from several particular attitudes in three fields, namely job factors, individual characteristics, and group relationship outside the job. Job factors refers to sex, age, education, and time of job. Based on Mishra (2013), women, older employees, uneducated employees tend to be more satisfied with their job than man, younger employees, and more educated employees. Individual characteristics could also influence employees' job satisfaction. According to Mishra (2013), this factor consists of type of work, skill required, occupational status and responsibility. In other words, employees who does routine work, unskilled, lacking of job knowledge are more likely to be dissatisfied with their career than vice versa. The last factor refers factors within the organizational policies and practices for instance wages, working condition, benefits, security, and opportunity for promotion. Mishra (2013) indicated that these factors, if properly implemented could influence the employee's satisfaction towards their jobs.

\section{Theory of Career Satisfaction: Social and Human Capital Theory}

According to Chen (2010), human capital and social capital are important elements to identify the factors affecting career success. In specific, age, sex and marital status can positively predict objective career success (Chen, 2010). For instance, female has a different level of objective career success than male because female is more favourable to receive the promotions or compensation by the company.

Besides that, human capital elements such as education level, area of education, organizational rank and tenure can positively predict objective career success (Chen, 2010). Individual with higher rank in the position can improve their competencies and gain more experience to develop their career, and indirectly it can allow them to achieve objective career success. As for social capital, social networks and social trust are two dimensions that could affect career success. Individuals with high social capital can broaden their network and get more trust in the organization (Chen, 2010). 
Apart from that, Guo et al (2012) also has stated that career success can be measured by three criteria namely internal competitiveness, external competitiveness and career satisfaction. Internal competitiveness refers to the individuals that felt themselves as a valuable person to the organization meanwhile external competitiveness refer to the individuals that felt like a valuable person to other organization. For external competitiveness, individuals felt that they are able to find their new career or work at the other organization. Different from career satisfaction, individuals with high career satisfaction means that they are satisfied with their current performance or current work.

\section{Impact of Organizational Career Management on Career Satisfaction}

A study conducted by Guan et al (2015) has found that there is an impact of perceived organizational career management on employees' career success. In addition, Tresna et al (2019); Hsiao (2013) have conducted similar study and the findings revealed a significant effect of career management towards the employees' career satisfaction. In other words, better career management practices would lead to an increase of the employees' career satisfaction. Other studies that have supported the linkage between career management and career satisfaction are for example Hsiao (2013); Kiong and Yin-Fah (2016); Uysal et al (2015). These studies have found significant relationship which suggests the influence of career management towards employees' attitudes. Specifically, organization could improve employees' career satisfaction by providing a more conducive environment for employees' learning and growth (Kiong \& Yin-Fah, 2016).

\section{Methodology}

\section{Research Design}

According to Akhtar (2016), research design refers to the research structure or planning for research. In this study, there are two types of research design which as descriptive statistics and inferential statistics. Descriptive statistics has been used to analyse the frequency, standard deviation and mean score in determining the level of organizational career management and the level of employees' career satisfaction. Additionally, inferential statistics has been used to answer the third objective which is the impact of organizational career management towards employees' career satisfaction.

\section{Population and Sampling}

Population refers to the target population that will be involved in a study (Majid, 2018). Meanwhile, sampling refers to the representative of the population (Taherdoost, 2016). This study has used snowball sampling as a method to determine the sample size. A total of 101 employees from a private sector firm in Johor have been involved in this study.

\section{Research Instrument}

Questionnaire was used as a major instrument to collect the data. There are 24 items in the questionnaire which comprised three parts. Section A consists of 5 items of respondent's demographic such as gender, age, race, education level and working experience. Section $B$ consists of 14 items of organizational career management that has been adapted from (Kumudha and Abraham, 2008). Section C consists of 5 items which measured career satisfaction that has been adapted from (Hofmans et al., 2008). All the items have been measured by using Five-point Likert scale where, 1 = Strongly Disagree and $5=$ Strongly Agree. In order to improve the study's reliability, pilot test has been conducted among 20 employees 
at a different company with similar nature of business. The finding shown all of the items have high level of reliability where the Cronbach's alpha value, $a=0.95$.

\section{Data Analysis}

Data that had been collected from the questionnaire has been analysed by using Statistical Package for the Social Sciences (SPSS). Descriptive statistics such as frequency and percentage have been used to present the demographic data. Meanwhile mean score, standard deviation has been used to identify the level of organizational career management and the level of employees' career satisfaction. Inferential statistics namely regression analysis has been used to identify the impact of organizational career management towards employees' career satisfaction.

\section{Research Findings}

\section{Demographic Analysis}

Table 1 shows the respondent's demographic information. In overall, $68.3 \%$ of respondents are female while $31.7 \%$ respondents are male. Most of the respondents of this study are between 21 to 30 years old (79.4\%). In terms of education level, most of the respondents are Degree holders (34.7\%) followed by Diploma holders (33.7\%). Furthermore, the findings shown that $33.7 \%$ of the respondents had 1 to 2 years of working experience and $2.0 \%$ of respondents had 5 to 6 years of working experience.

Table 1: Respondents Demographic Analysis

\begin{tabular}{llll}
\hline Factors & Category & $\begin{array}{l}\text { Frequency } \\
\text { (f) }\end{array}$ & $\begin{array}{l}\text { Percentage } \\
\text { (\%) }\end{array}$ \\
\hline Gender & Male & 32 & 31.7 \\
& Female & 69 & 68.3 \\
\hline Age & Below 20 years old & 3 & 3.0 \\
& $21-30$ years old & 80 & 79.2 \\
& $31-40$ years old & 14 & 13.9 \\
& $41-50$ years old & 4 & 4.0 \\
\hline Education Level & SPM & 21 & \\
& STPM & 4 & 20.8 \\
& Diploma & 34 & 4.0 \\
& Degree & 35 & 33.7 \\
& Master & 1 & 34.7 \\
& Others & 6 & 1.0 \\
& Below 1 year & 33 & 5.9 \\
\hline Working Experience & $1-2$ years & 34 & 32.7 \\
& $3-4$ years & 32 & 33.7 \\
& 5 - 6 years & 2 & 31.7 \\
& & & 2.0 \\
\hline
\end{tabular}

\section{The Level of Organizational Career Management}

Table 2 illustrates the frequency, standard deviation and mean score for the employees' perceived organizational career management. The findings found that the level of employees' perceived organizational career management was high (mean score $=3.76$ ). 
Table 2: Statistic descriptive of organizational career management

\begin{tabular}{|c|c|c|c|c|c|c|c|}
\hline & $\begin{array}{l}\text { SD } \\
f \\
(\%)\end{array}$ & $\begin{array}{l}\text { DS } \\
f \\
(\%)\end{array}$ & $\begin{array}{l}\text { NAnD } \\
f \\
(\%)\end{array}$ & $\begin{array}{l}\text { AS } \\
f \\
(\%)\end{array}$ & $\begin{array}{l}\text { SA } \\
f \\
(\%)\end{array}$ & $\begin{array}{l}\text { Mean } \\
\text { (SD) }\end{array}$ & Level \\
\hline $\begin{array}{l}\text { My organization uses } \\
\text { Performance Appraisal } \\
\text { as a basis for career } \\
\text { planning }\end{array}$ & 0 & 5.9 & 15.8 & 42.6 & 35.6 & 0.868 & High \\
\hline $\begin{array}{l}\text { I receive career } \\
\text { counselling by direct } \\
\text { supervisor }\end{array}$ & 1.0 & 12.9 & 23.8 & 35.6 & 26.7 & 1.026 & High \\
\hline 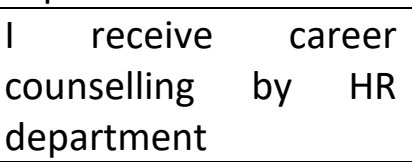 & $\begin{array}{l}7 \\
6.9\end{array}$ & 8.9 & 29.7 & 27.7 & 26.7 & $\begin{array}{l}3.58 \\
1.177\end{array}$ & $\begin{array}{l}\text { Moderat } \\
\mathrm{e}\end{array}$ \\
\hline $\begin{array}{l}\text { My organization } \\
\text { provides mentoring to } \\
\text { employees }\end{array}$ & 5.0 & 3.0 & 23.8 & 32.7 & 35.6 & $\begin{array}{l}3.91 \\
1.078 \\
\end{array}$ & High \\
\hline $\begin{array}{l}\text { I have attended career } \\
\text { workshops in my } \\
\text { organization }\end{array}$ & $\begin{array}{l}10 \\
9.9 \\
\end{array}$ & 7.9 & 11.9 & 27.7 & 42.6 & $\begin{array}{l}3.85 \\
1.322 \\
\end{array}$ & High \\
\hline $\begin{array}{l}\text { My organization } \\
\text { provides books and/or } \\
\text { pamphlets on career } \\
\text { issues }\end{array}$ & 6.9 & 8.9 & 33.7 & 18.8 & 31.7 & 1.218 & $\begin{array}{l}\text { Moderat } \\
\mathrm{e}\end{array}$ \\
\hline $\begin{array}{l}\text { My organization } \\
\text { appreciates and } \\
\text { supports individual } \\
\text { developmental efforts }\end{array}$ & 2.0 & 4.0 & 23.8 & 35.6 & 34.7 & 0.964 & High \\
\hline $\begin{array}{lr}\text { My } & \text { organization } \\
\text { supplies } & \text { full } \\
\text { information about job } \\
\text { openings }\end{array}$ & 3.0 & 5.9 & 16.8 & 38.6 & 35.6 & $\begin{array}{l}3.98 \\
1.020\end{array}$ & High \\
\hline $\begin{array}{l}\text { My organization } \\
\text { develops career plans } \\
\text { with individuals }\end{array}$ & $\begin{array}{l}4 \\
4.0 \\
\end{array}$ & $\begin{array}{l}12 \\
11.9\end{array}$ & $\begin{array}{l}21 \\
20.8 \\
\end{array}$ & $\begin{array}{l}38 \\
37.6 \\
\end{array}$ & $\begin{array}{l}26 \\
25.7\end{array}$ & $\begin{array}{l}3.69 \\
1.102 \\
\end{array}$ & High \\
\hline $\begin{array}{lr}\text { My } & \text { organization } \\
\text { adopts a policy of first } \\
\text { filling } \\
\text { internally }\end{array}$ & 5.0 & 4.0 & 23.8 & 40.6 & 26.7 & 1.039 & High \\
\hline $\begin{array}{l}\text { My organization } \\
\text { rewards competence } \\
\text { by promotion }\end{array}$ & 5.0 & 10 & 22 & 29.7 & 33.7 & 3.77 & High \\
\hline $\begin{array}{l}\text { My organization sends } \\
\text { employees on job } \\
\text { rotation schemes }\end{array}$ & 12 & 11 & 25 & 32 & 21 & 3.39 & $\begin{array}{l}\text { Moderat } \\
\mathrm{e}\end{array}$ \\
\hline
\end{tabular}


INTERNATIONAL JOURNAL OF ACADEMIC RESEARCH IN BUSINESS AND SOCIAL SCIENCES Vol. 11, No. 11, 2021, E-ISSN: 2222-6990 @ 2021 HRMARS

\begin{tabular}{|c|c|c|c|c|c|c|c|}
\hline $\begin{array}{lr}\text { My organization } \\
\text { organizes retirement } \\
\text { preparation programs }\end{array}$ & 10.9 & 15.8 & 20.8 & 23.8 & 28.7 & 1.345 & $\begin{array}{l}\text { Moderat } \\
\mathrm{e}\end{array}$ \\
\hline $\begin{array}{l}\text { I am encouraged by the } \\
\text { management to take } \\
\text { up formal education as } \\
\text { part of career } \\
\text { development }\end{array}$ & 5.9 & 7.9 & 12.9 & 37.6 & 35.6 & $\begin{array}{l}3.89 \\
1.157\end{array}$ & High \\
\hline Total Mean & & & & & & $\begin{array}{l}3.76 \\
0.861\end{array}$ & High \\
\hline
\end{tabular}

*Note: 5-Likert Scale used, where SD=Strongly Disagree, DS=Disagree Somewhat, $\mathrm{NAnD}=$ Neither Agree nor Disagree, $\mathrm{AS}=$ Agree Somewhat, $\mathrm{SA}=$ Strongly Agree, $\mathrm{f}=$ frequency, $\%=$ percentage, $\mathrm{SD}=$ Standard Deviation

Based on Table 2, item 1 "My organization uses Performance Appraisal as a basis for career planning" had the highest mean score $(M=4.08)$ followed by item 7 "My organization supplies full information about job openings" ( $M=3.98)$ and item 6 "My organization appreciates and supports individual developmental efforts" (M=3.97). The lowest mean score was for item 11 "My organization sends employees on job rotation schemes" with mean score $(M=3.39)$ followed by item 12 "My organization organizes retirement preparation programs" $(M=3.44)$ and item 3 "I receive career counselling by HR department" $(M=3.58)$. The average mean score of 3.76 suggests that the company implemented most of the career management practices that were investigated in this study.

\section{The Level of Employees' Career Satisfaction}

Table 3 displays the frequency, standard deviation and mean score for employees' perceived career satisfaction. The findings indicated the level of employees' perceived career satisfaction was high $(\mathrm{M}=3.88)$. 
Table 3: Statistic descriptive of employees' career satisfaction

\begin{tabular}{|c|c|c|c|c|c|c|c|}
\hline Item & $\begin{array}{l}\text { SD } \\
f \\
(\%)\end{array}$ & $\begin{array}{l}\text { DtSE } \\
f \\
(\%)\end{array}$ & $\begin{array}{l}\text { U } \\
f \\
(\%)\end{array}$ & $\begin{array}{l}\text { AtSE } \\
f \\
(\%)\end{array}$ & $\begin{array}{l}\text { SA } \\
f \\
(\%)\end{array}$ & $\begin{array}{l}\text { Mean } \\
\text { (SD) }\end{array}$ & Level \\
\hline $\begin{array}{l}\text { I am satisfied with the } \\
\text { success I have achieved } \\
\text { in my career }\end{array}$ & 4.0 & 5.9 & 18.8 & 41.6 & 29.7 & 3.87 & High \\
\hline $\begin{array}{l}\text { I am satisfied with the } \\
\text { progress I have made } \\
\text { towards meeting my } \\
\text { overall career goals }\end{array}$ & 1.0 & 5.0 & 24.8 & 42.6 & 26.7 & 0.893 & High \\
\hline $\begin{array}{l}\text { I am satisfied with the } \\
\text { progress I have made } \\
\text { towards meeting my } \\
\text { goals for income }\end{array}$ & 4.0 & 7.9 & 25.7 & 27.7 & 34.7 & 3.81 & High \\
\hline $\begin{array}{l}\text { I am satisfied with the } \\
\text { progress I have made } \\
\text { towards meeting my } \\
\text { goals for advancement }\end{array}$ & 2.0 & 5.9 & 28.7 & 39.6 & 23.8 & $\begin{array}{l}3.77 \\
0.947\end{array}$ & High \\
\hline $\begin{array}{l}\text { I am satisfied with the } \\
\text { progress I have made } \\
\text { towards meeting my } \\
\text { goals for the } \\
\text { development of new } \\
\text { skills }\end{array}$ & 1.0 & 3.0 & 17.8 & 46.5 & 31.7 & $\begin{array}{l}4.05 \\
0.841\end{array}$ & High \\
\hline
\end{tabular}

Total Mean

$3.88 \quad$ High

0.862

*Note: 5-Likert Scale used, where SD=Strongly Disagree, DtSE=Disagree to Some Extent, $\mathrm{U}=$ Uncertain, AtSE=Agree to Some Extent, $\mathrm{SA}=$ Strongly Agree, $\mathrm{f}=$ frequency, \%=percentage, $\mathrm{SD}=$ Standard Deviation

Based on the Table 3, the findings show that item 5 "I am satisfied with the progress I have made towards meeting my goals for the development of new skills" had the highest mean score $(M=4.05)$. Meanwhile, item 4 "I am satisfied with the progress I have made towards meeting my goals for advancement" had the lowest mean score $(M=3.77)$. The average mean score of 3.88 suggests that the employees were mostly satisfied with their career.

The Impact of Organizational Career Management towards Employees' Career Satisfaction Table 4 and 5 report the result of regression analysis for the third objectives. The findings shown that $68.2 \%$ of employees' perceived career satisfaction can be explained by organizational career management. This means that $31.8 \%$ of the employees' career satisfaction could be contributed by other factors. Furthermore, the $p$ value is less than 0.005 $(p<0.005)$ which suggests a significant impact of organizational career management towards employees' career satisfaction. 
Table 4: Model summary

\begin{tabular}{lllll}
\hline Model & $\mathbf{R}$ & $\mathbf{R}$ Square & Adjusted R Square & Std. Error of the Estimate \\
\hline 1 & $.826^{\mathrm{a}}$ & .682 & .679 & .48833 \\
\hline
\end{tabular}

a. Predictors: (Constant), Organizational_Career_Management

b. Dependent Variable: Employees_Career_Satisfaction

Table 5: ANOVA

\begin{tabular}{lllllll}
\hline Model & $\begin{array}{l}\text { Sum } \\
\text { Squares }\end{array}$ & of & $\begin{array}{l}\text { Mean } \\
\text { Square }\end{array}$ & F & Sig. \\
\hline 1 & Regression & 50.718 & 1 & 50.718 & 212.683 & $.000^{\mathrm{a}}$ \\
\cline { 2 - 7 } & Residual & 23.608 & 99 & .238 & & \\
\hline Total & 74.326 & 100 & & &
\end{tabular}

c. Predictors: (Constant), Organizational_Career_Management

d. Dependent Variable: Employees_Career_Satisfaction

\section{Discussion}

The first objective of this study was to determine the level of employees' perceived career management practices. The results suggest that the level of organizational career management is high, while the activities and practices provided by the organization can develop employee's careers. The process of developing the employees' career must take into consideration both individual needs and organizational goals. Performance appraisal could be used as a basis for career planning to help organization in identifying the individual's' needs and interests. The findings are linked with the previous study by Albay and Serbes (2017), where career planning has involved the decision-making process of identifying individual's needs and interests. Furthermore, full information regarding the job openings in the organization provides employee with a clearer direction of their career path which then would motivates them to upgrade their skills and capabilities. Employees will be more satisfied with their career as the could plan for their career development within the organization. The finding is supported by Hsiao (2013) who indicated that career information can be a contributor to career management that leads to employees' satisfaction. Besides that, career workshops are also another important activity that can help to develop the employees' career. For example, in a previous study by Rezaean et al (2012) found that in-house training and career workshops can help to improve the employees' knowledge, skills and abilities (KSA), thereafter improving their chances for a career promotion.

The second objective of this study was to identify the level of employees' career satisfaction. The results suggest that the employees shown a high career satisfaction. This means that the employees are satisfied with the career management such development opportunities provided by the organization. The findings are linked with the previous study by Fugar et al (2013) who indicated that training can improve employees' knowledge. Besides that, the result also shown that most of the employees are satisfied with their progress in meeting the overall goals. As mentioned by Shockley et al. (2016), career satisfaction can be measured by various factors including achieving the overall goals, pay, improvement in one's career, and increased expertise through development activities. 
Lastly, the third objective of this study was to determine the impact of organizational career management towards employees' career satisfaction. The results revealed a positive impact between the two variables. In other words, employees' career satisfaction could be impacted by the organizational career management practices. Positive impact between these two variables have been proven by many previous studies such as Hsiao (2013); Kiong and Yin-Fah (2016); Uysal et al (2015); Tresna et al (2019). The findings of this study suggest that better career management practices would lead to an increase of the employees' career satisfaction. Based on the findings of this study, the researchers suggest that organization uses performance appraisal as a basis for career planning such as by collecting information regarding employees' career goals and interest. This would allow the organization to tailor the individual employees' needs with the organizational goals. Besides that, organization should also conduct career counselling, mentoring, career workshop, and development programs to support the employees' career planning within the organization (Rezaean et al., 2012; Kiong \& Yin-Fah, 2016). Satisfied employees ultimately are more likely to retain in their jobs which indirectly reduces turnover intention (Uysal et al., 2005). This is because employees felt that the organization is supporting their career growth within the organization by creating a positive environment for employees learning and growth (Kiong and Yin-Fah, 2016).

\section{Conclusion}

In conclusion, this study has revealed a significant impact of organizational career management practices on employees' perceived career satisfaction. Besides that, this study has also found that there are other factors besides organizational career management which could influence the employees' perceived career satisfaction. Therefore, future researchers are encouraged to explore or enhance the aspects of organizational career management practices which was not measured in this study. Moreover, as the findings of this study are only limited to two variables namely organizational career management and career satisfaction, future researchers could explore other variables such as turnover intention as another attitudinal effect resulting from career satisfaction. Besides that, this study has looked at career satisfaction as one element. Future studies may want to distinguish this variable into objective and subjective career success. In overall, the findings of this study contribute to the career literature by offering empirical evidence which further strengthen the linkage between organizational career management practices and employees career satisfaction.

\section{References}

Abutayeh, B. K. (2017). The Role of High-Performance Work System on Career Success: Evidence from Jordan. International Journal of Business and Management, 12(10), 203-211.

Akhtar, M. I. (2016). Research Design. Research in Social Science: Interdisciplinary Perspectives, 68-84.

Albay, M., \& Serbes, M. (2017). Importance of Career Planning and Development in Education. International Journal of Social Sciences \& Educational Studies, 4(2), 149-154.

Atli, A. (2016). The Effects of Trait-factor Theory Based Career Counseling Sessions on the Levels of Career Maturity and Indecision of High School Students. Universal Journal of Educational Research 4(8), 1837-1847. 
Bagdadli, S., \& Gianecchini, M. (2018). Organizational career management practices and objective career success: A systematic review and framework. Human Resource Management Review, 29(3), 353-370.

Chen, Y. (2010). Career Success of Knowledge Workers: The Effects of Perceived Organizational Support and Person-Job Fit. iBusiness, 2(4), 389-394.

Dorasamy, N., \& Letooane, M. K. (2015). Job and career satisfaction in higher education institutions: a case study of university "A" in South Africa. Problems and Perspectives in Management, 13(4), 258-269.

Fugar, F. D., Ashiboe-Mensah, N. A., \& Adinyira, E. (2013). Human capital theory: Implications for the Ghanaian construction industry development. Journal of Construction Project Management and Innovation, 3(1), 464-481.

Guan, Y., Zhou, W., Ye, L., Jiang, P., \& Zhou, Y. (2015). Perceived organizational career management and career adaptability as predictors of success and turnover intention among Chinese employees. Journal of Vocational Behavior, 88, 230-237.

Guo, W., Xiao, H., \& Yang, X. (2012). An empirical research on the correlation between human capital and career success of knowledge workers in enterprise. Physics Procedia, 25, 715-725.

Hofmans, J., Dries, N., \& Pepermans, R. (2008). The Career Satisfaction Scale: Response bias among men and women. Journal of vocational behavior, 73(3), 397-403.

Hsiao, J. M. (2013). Organizational Career Management, Job Satisfaction and Organizational Commitment: A Case Study of Car Dealer in Taiwan. Actual Problems of Economics, 3(141), 432-440.

Kiong, T. P., \& Yin-Fah, B. C. (2016). Exploring Factors towards Career Success in Malaysia. International Busines Management, 10(17), 3936-3943.

Kong, H., Cheung, C., \& Zhang, H. Q. (2010). Career management systems: what are China's state-owned hotels practising? International Journal of Contemporary Hospitality Management, 22(4), 467-482.

Kumudha, A., \& Abraham, S. (2008). Organization Career Management and Its Impact on Career Satisfaction: A Study in the Banking Sector. The ICFAI University Journal of Bank Management, 7(3), 48-58.

Majid, U. (2018). Research Fundamentals: Study Design, Population, and Sample Size. Undergraduate Research in Natural and Clinical Science and Technology Journal, 2(1), 1-7.

Mishra, P. K. (2013). Job Satisfaction. IOSR Journal of Humanities and Social Science, 14(5), 4554.

Naqvi, S. R., Mahmood, Q., Minhas, A. A., Khattak, J., \& Malik, F. (2013). Impact of organizational career management activities on organizational commitment: A case of IT companies of Pakistan. Scholarly Journal of Business Administration, 3(1), 7-11.

Ogar, C. A., Igwe, M. N., \& Effenji, F. I. (2019). Career Management Practices: The Nigerian Employees' Experience. International Journal of Economics, Commerce, and Management, 7(5), 593-625.

Rahim, N. B., \& Siti-Rohaida, M. Z. (2015). Career Satisfaction and Psychological Well-Being among Professional Engineers in Malaysia: The Effect of Career Goal Development. Asian Academy of Management Journal, 20(2), 127-146.

Rezaean A., Hatami S., \& Dastar H. (2012). Relationship between career management and career satisfaction. Iranian Journal of Military Medicine, 13(4), 217-221. 
Seema, A., \& Sujatha, S. (2013). Conceptual work on career management strategies from an organization perspective. International Journal of Management, IT and Engineering, 3(7), 184-198.

Shockley, K. M., Ureksoy, H., Rodopman, O. B., Poteat, L. F., \& Dullaghan, T. R. (2016). Development of a new scale to measure subjective career success: A mixed-methods study. Journal of Organizational Behavior, 37(1), 128-153.

Taherdoost, H. (2016). Sampling Methods in Research Methodology; How to Choose a Sampling Technique for Research. International Journal of Academic Research in Management, 5(2), 18-27.

Tresna, P. W., Muhyi, H. A., \& Bagaskara, R. S. (2019). Career Management and Its Effect on Employee Job Satisfaction. Review of Integrative Business and Economics Research, 8(2), 209-221.

Uysal, S., Şahin, K., Çetin, G., \& Dinçer, F. I. (2015). Career management in hospitality: The case of four and five star hotels in Istanbul. Istanbul University Econometrics and Statistics e-Journal, (22), 1-13.

Xueling, P. E. I. (2017). Empirical Study of Career Management and Engagement. Canadian Social Science, 13(1), 43-48. 